\title{
ASSESSMENT OF PHYSICAL AND CHEMICAL QUALITY OF DRINKING WATER IN ELOBEID CITY, NORTH KORDOFAN STATE, SUDAN
}

\author{
Halima Brima Gama Tigaidi ${ }^{1}$ \\ ${ }^{1}$ Department of Environmental Health, \\ Faculty of Public and Environmental Health, \\ University of Kordofan, Sudan
}

\author{
Dr. Mohammed Ismail Humaida ${ }^{2,3}$ \\ ${ }^{2}$ Department of epidemiology, \\ Faculty of Public and Environmental Health, \\ University of Kordofan, \\ Sudan \\ ${ }^{3}$ Department of Public Health, \\ Faculty of Public Health and Health \\ Informatics, \\ University of Hail, \\ KSA
}

\author{
Dr.Kubra Ali Ebrahim Hammad ${ }^{2}$ \\ ${ }^{2}$ Department of Epidemiology, \\ Faculty of Public and Environmental Health, \\ University of Kordofan, \\ Sudan
}

Article DOI: https://doi.org/10.36713/epra4840

\begin{abstract}
This study was conducted in El-Obied City, North Kordofan State.The study comprised of 54 samples of water selected from houses, animal carts (karo), tankers, gerbas and main source of water bara basin and El-khazan (surface water )in El-Obied. The sample was divided over these sources following a process of stratified sampling combined with simple random samples with probability proportional to size of sample over the selected blocks where selection was at random in each stage. Physical and chemical testing of water was done using standard procedures. Two Samples of water were collected from the main sources of water in the City for physical and chemical analysis and 52 samples collected from blocks. The data were analyzed by computer. This study showed that 50\% of the samples were without residual chlorine, and only $1.8 \%$ of samples were soft water.

The study showed that 3.7\% of samples had pH above WHO and SSMO Standard and also showed 18.5\% of samples had turbidity above $5 \mathrm{NTU}$.
\end{abstract}

KEY WORDS: Assessment, physical, chemical, drinking water, El-Obied

\section{INTRODUCTION}

Water is basic to support life, and a palatable (satisfactory, secure and available) supply must be accessible to all. Progressing get to secure drinking water can result in unmistakable benefits to wellbeing. Each exertion ought to be made to attain drinking water that's as secure as practicable (WHO, 2011). The essential capacities of society require water: cleaning for open wellbeing, utilization for mechanical forms, and cooling for electrical era (Weiner and Matthews, 2003). Africa had the least water supply access of any locale within the world at the starting of the decade. The overall populace with get to a progressed water supply in 2000 was $62 \%$, whereas that for progressed sanitation was $60 \%$, (WHO-UNICEF, 2000). In this way the number of individuals without get to secure water and sanitation is 300 million and 313 million 
individually, Get to secure water in rural Africa is as it were $47 \%$. As of 2008 , the most recent year for which information are accessible from the UNICEF/WHO"s Joint Monitoring Program (JMP), Sub-Saharan Africa accounted for over a third of the 822 million individuals without get to made strides water supply. The locale as a entire is slacking behind in advance towards the MDG target, with $60 \%$ of the populace utilizing progressed sources of drinking-water in spite of an increment of 11 rate focuses since 1990, (ADBG, 2003). The arrangement of an satisfactory supply of secure water is one of the eight components of essential wellbeing care recognized by the Universal Conference on Essential Wellbeing Care in Alma-Ata in 1978 (WHO, 1997). Much of the ill-health which influences humankind, particularly within the creating nations can be followed to need of secure and wholesome water supply. (Park's, 2015). Surface water begins from rain water. It's the most source of water supply in numerous ranges. Illustrations of surface water incorporate waterways, lakes, watercourses (water source which are dry, but in stormy season ), manmade supplies and ocean water (Park, 2015).

\section{MATERIAL AND METHODS \\ Study Design \\ Descriptive cross-sectional study. \\ Study area}

El-Obeid City is the biggest City in the North Kordofan State. El-Obied is one of the most important cities in North Kordofan and the capital of the North Kordofan State. Its area have been estimated as $81 \mathrm{~km}$ square and the distance from Khartoum is about $560 \mathrm{~km}$. The population of the City is estimated as 440483 persons. There are 38000 houses, 40000 families in the City.

\section{Study population}

Water supplies

\section{Inclusion criteria}

Water distribution to household by animal's carts (karo) especially the far household, as well as water from tankers and gerbas, samples from housing and distribution network.

\section{Exclusion criteria}

Water from intake and surface water (haffirs).

\section{Sampling}

\section{Sample Size}

Sample size was selected according to (WHO) guidelines for water sampling measurement, which recommend to take one sample per 10,000 population, plus 10 additional samples, (WHO, 1997).

Number of population: 440483

Sample size: 44 sample +10

Accordingly, a sample of 54 samples were obtained.

\section{Sampling technique}

El-Obied, City was divided into four equal quarters (Clusters). The different types of blocks are considered as strata where 13 samples was selected from each quarter of El-Obeid City by using a process of simple random sample, and 2 samples were selected from water distribution network, so the total number of samples selected is $\mathbf{5 4}$ samples from all blocks.

\section{Data collection methods and tools: Samples Collection:-}

Water samples for physical \& chemical testing were collected in the sterilized bottle. The outside of the tap sterilized by flame, and then water allowed running for two minutes to wash out any organism in the pipe. The bottle then filled with water and closed immediately. A total of water samples of each in tightly sealed sterile bottles packed in cool box then submitted to ministry of health laboratory in ElObied in the same day for analysis.

\section{Chemical testing of water}

- Chemical testing of water done by measuring of :

- $\mathrm{pH}$,

- Chlorine,

- Fluoride,

- Hardness,

- Nitrite,

Theses test done by using photometer

Physical testing of water

To measure turbidity and colour.

\section{Test Method}

\section{Colour:}

Reagents and equipment

Palintest colour/turbidity set.

Palintest automatic wavelength selection photometer.

\section{Turbidity}

\section{Reagents and equipment}

Palintest colour/turbidity set.

Palintest automatic wavelength selection photometer.

\section{Data processing \& analysis}

After taking samples, data were analyzed using Statistical Package for Social Sciences (SPSS) and presented by tables and figures.

\section{Ethical consideration}

Ethical permission for the study obtained prior collection of data. The researcher contact and received approval from the appropriate management authority.

\section{RESULTS}

The study was conducted in EL-Obied, city. To assessment physical \& chemical quality of drinking water in EL-Obied City, North kordofan State. The obtained result was recorded as follow: 


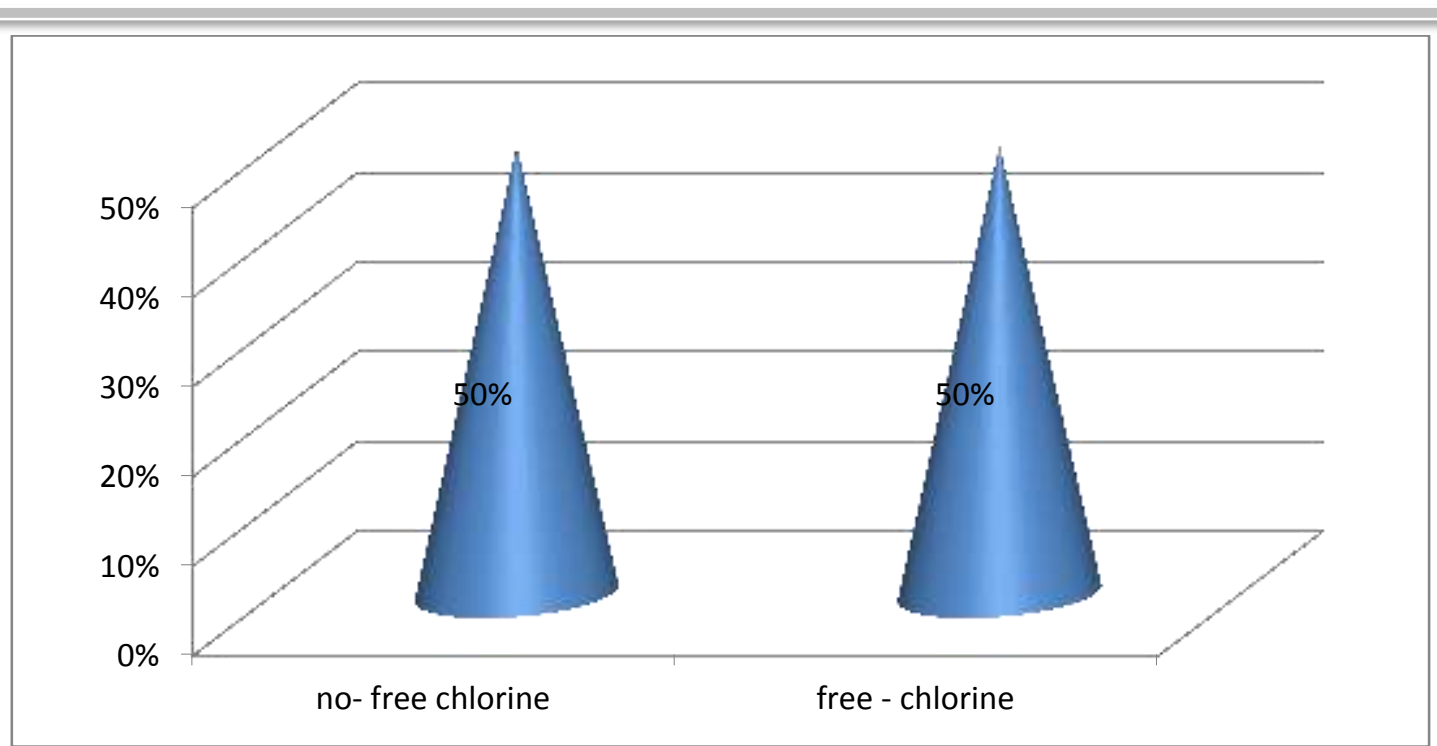

Figure (1): The distribution of residual chlorine among samples in EL-Obied city $\mathrm{n}=54$

Table (1) the chemical parameter of water and comparative with SSMO and WHO standard - in ElObeid city $\mathrm{n}=54$

\begin{tabular}{|l|c|c|c|c|c|c|}
\hline Parameter & Mean & $\begin{array}{c}\text { Standard } \\
\text { deviation }\end{array}$ & SSMO & $\begin{array}{c}\text { Sample } \\
\text { above }\end{array}$ & WHO & Sample above \\
\hline PH & 8 & 1 & $6.5-8.5$ & $3.7 \%$ & $6.5-8.5$ & $3.7 \%$ \\
\hline Hardness & 187 & 90 & NS & - & $0-60$ & 98.1 \\
\hline Fluoride & 0.58 & 0.57 & 1.5 & 0 & 1.5 & 0 \\
\hline Residual chlorine & 0.15 & 0.23 & 0.5 & $20.3 \%$ & 0.5 & $20.3 \%$ \\
\hline Nitrite & 0.029 & 0.045 & 2 & 0 & 3 & 0 \\
\hline
\end{tabular}

Table (2) the degree of hardness for water - in EL-obied city $n=54$

\begin{tabular}{|c|c|c|c|c|}
\hline Parameter & $\begin{array}{c}\text { Less than 50 } \\
\text { (soft) }\end{array}$ & $\mathbf{5 0 - 1 5 0 ( m o d e r a t e l y ~ h a r d ) ~}$ & $\mathbf{1 5 0 - 3 0 0 ( h a r d )}$ & Above300(very hard) \\
\hline Hardness & $1.8 \%$ & $40.7 \%$ & $46.2 \%$ & $11.1 \%$ \\
\hline
\end{tabular}

Table (3) the physical parameter of water and comparative with SSMO and WHO standard - in ELobied city

\begin{tabular}{|l|c|c|c|c|c|c|}
\hline Parameter & Mean & $\begin{array}{c}\text { Standard } \\
\text { deviation }\end{array}$ & SSMO & Sample above\% & WHO & $\begin{array}{c}\text { Sample } \\
\text { above\% }\end{array}$ \\
\hline Turbidity & 5 & 15 & 5 NTU & $18.5 \%$ & 5 NTU & $18.5 \%$ \\
\hline Colour & 25 & 114 & 15 TCU & $25 \%$ & 15 TCU & $35 \%$ \\
\hline
\end{tabular}




\section{DISCUSSION}

This cross sectional study was carried out in El-Obied City, North kordofan State, Sudan to assess of physical \& chemical quality of drinking water.

This study showed that $3.7 \%$ only of samples contained $\mathrm{pH}$ above SSMO and WHO Standard (Table:1), that means $3.7 \%$ from samples tend to alkaline, At $\mathrm{pH}$ levels above 8 , there is a progressive decrease in the efficiency of the chlorine disinfection process. (Park's, 2015). and 50\% samples without residual chlorine, that residual chlorine mean is 0 $\mathrm{mg} / \mathrm{l}$ that is less than recommended value of WHO guideline and SSMO Standards, which is equal 0.5 $\mathrm{mg} / 1$ in both, that make water more vulnerable to contamination because free residual chlorine provides a margin of safety against subsequent microbial contamination such as may occur during storage and distribution of water (Park's, 2015).

Most of water samples table (2); hard water and only $1.9 \%$ are soft water WHO guidelines shown hardness above $200 \mathrm{mg} / \mathrm{liter}$, can result in scale deposition, particularly on heating. Soft waters with a hardness of less than about $100 \mathrm{mg} /$ liter have a low buffering capacity and may be more corrosive to water pipes. No health-based guideline value is proposed for hardness. However, the degree of hardness in water may affect its acceptability to the consumer in terms of taste and scale deposition (WHO-2011).

The study illustrated that the value of turbidity of water distributed Table (3) about $18.5 \%$ above WHO and SSMO standard. This turbidity value exceed the maximum of WHO and SSMO standards , which equal 5 NTU for both this value is nonpreferable because high turbidity interferes with disinfection and microbiological determination. (Park's, 2015)

\section{CONCLUSIONS}

From the results and findings of the present investigation, it can be Concluded that:

The study illustrated that the concentrations of residual chlorine in most samples were zero, the other problem may be related to the road vendor of water who uses unclean tankers and unsafe water sources. Generally, it may be concluded that El.obied city drinking water has suitable physical and chemical quality as for drinking.

\section{REFERENCES}

1. ADBG, An Internal Assessment of the Rural Water Supply and Sanitation Initiative (20032009),

2. Prak,K (2015). Parks Textbook of Preventive and Social Medicine $\left(23^{\text {th }}\right.$ ed). Banarsidas. Bhanot. Jabalpur: pp:617-619, 631

3. Sheikan locality (2016). Administration of health affairs. North Kordofan State. El-Obied. Unpublished report.
4. SSMO, (2007).Sudanese standard for water quality, Sudan.

5. UNEP/WHO (1997), water supply and sanitation $\left(2^{\text {nd }}\right.$ ed).New York: PP: 23.

6. UNICEF (2008). UNICEF Handbook on Water Quality. UNICEF. New York: pp: 179.

7. Weiner, R,E; Matthews, R,A (2003). Environmental Engineering $\left(4^{\text {th }} e d\right)$. Elsevier Science. Burlington: pp: 458.

8. WHO (1997). Guidelines for drinking-water quality $\left(2^{\text {nd }}\right.$ ed) Vol(3): Surveillance and control of community supplies. WHO. Geneva: pp: 238

9. WHO (1998). Guidelines for Drinking-Water Quality: Health Criteria and Other Supporting Information (2 $2^{\text {nd }}$ ed) Vol(2). World Health Organization. Geneva: pp: 234.

10. WHO (2011). Guidelines for drinking-water quality $\left(4^{\text {th }} e d\right)$. World Health Organization. Geneva: pp: 541 